\title{
Recurrented bilateral low-dose regional anesthesia under ultrasound guidance rather than general anesthesia in a high-risk patient: Rare a case
}

\author{
Yüksek riskli yanıklı hastada genel anestezi yerine ultrasonografi eşliğinde düşük doz \\ mükerrer bilateral rejyonel anestezi: Nadir bir olgu
}

(D) Fikret SALIK, (1) Ümit AKOL, (1) Hakan AKELMA, @ Mustafa BIÇAK

\begin{abstract}
Summary
Regional anesthesia practices are important because they have the advantages, for example, the patient's awareness is open, spontaneous breathing continues, airway reflexes are preserved, analgesia continues in the post-operative period, and the patient has early mobilization. Local anesthetic at high doses and volumes are used in brachial plexus blocks with nerve stimulator. However, due to the development in ultrasound (US) technology and the increase in image quality, reduced dose of limited anesthesia, and because of its advantages such as vascular and reduced risk of pleural puncture, it has become increasingly widespread. Through US, it is possible to monitor the nerves and anatomical structures, to follow the needle, and to reduce the dose by monitoring the distribution of the local anesthetic given. Organ and tissue losses and tissue infections due to multiple exothermic burns, especially after burns, require multiple surgical procedures. While taking these patients to surgery, anesthesiologists may have difficulty in many stages. For this purpose, they prefer regional anesthesia for less complications. In our study, we aimed to present a low-dose bilateral supraclavicular, infraclavicular, and axillary block with US-guided paraplegic high-risk trauma in a patient with bilateral wounds, forearms, wrists, and wounds caused by burns.
\end{abstract}

Keywords: Bilateral brachial plexus blocks; burn; high-risk patient ultrasound

\begin{abstract}
Özet
Rejyonel anestezi uygulamaları hastanın bilincinin açık olması, spontan solunumunun devam etmesi, havayolu reflekslerinin korunması, postoperatif dönemde analjezinin devam etmesi ve hastanın erken mobilizasyonu gibi avantajları olduğundan önemlidir. Sinir stimülatörü kullanarak yapılan brakiyal pleksus bloklarında yüksek doz ve volümlerde lokal anestezik kullanılır. Ancak Ultrason (US) teknolojinin gelişmesi ve görüntü kalitesinin artması, daha düşük dozda sınırlı anestezi sağlayabilmesi, vasküler ve plevral ponksiyon riskinin azaltması gibi avantajlarından dolayı kullanımı giderek yaygınlaşmıştır. Ultrason (US) ile sinirlerin ve anatomik yapıların izlenebilmesi, iğnenin takip edilebilmesi, verilen lokal anesteziğin dağılımının izlenerek dozun azaltılabilmesi mümkün olabilmektedir. Özellikle yanık sonrası oluşan çoklu ekstermite yanıklarına bağlı organ ve doku kayıpları, doku enfeksiyonu çoklu cerrahi işlemleri gerektirir. Bu hastaları cerrahiye alırken anestezistler birçok aşamada zorluk çekebilirler. Bu amaçla daha az komplikasyon oluşması için rejyonel anestezi tercih ederler. Çalışmamızda elektrik yanığına bağlı bilateral her iki kol, önkol, el bileği ve elde gelişen yanık yarası olan ve ek olarak akciğer hastalığı bulunan paraplejik yüksek riskli travma olgusunda US eşliğinde uyguladığımız düşük doz bilateral supraklaviküler, infraklaviküler ve axiller bloğu sunmayı amaçladık.
\end{abstract}

Anahtar sözcükler: Bilateral brakiyal pleksus blokları; ultrason; yanık; yüksek riskli hasta.

\section{Introduction}

The application of regional anesthesia has significant advantages, such as the patient being conscious, being able to express complaints, continuation of spontaneous respiration, protection of airway reflex- es, continuation of analgesia in the post-operative period, and early mobilization of the patient. ${ }^{[1]}$ In upper extremity blocks, it is important that the doctor performing the procedure has good knowledge of the brachial plexus anatomy and the information of 
which blocks should be applied to which patients for what purpose is crucial. ${ }^{[2]}$ The use of local anesthetic at a high dose and volume in brachial plexus blocks applied using a nerve stimulator is an important determinant of the success of the block. Bilateral brachial plexus block is not often applied because of the risk of systemic local anesthetic toxicity. ${ }^{[3]}$ With ultrasound (US), it is possible to visualize the anatomic structures, to follow the course of the needle, and to reduce the dose by observing the distribution of the local anesthetic given. The use of US also provides visualization of the structures, which require protection, such as nerves, pleura, and blood vessels. ${ }^{[4]}$

The case is here presented of a high-risk trauma patient with burn injuries to the bilateral arms, forearms, wrists, and hands from an electrical burn, and the patient also had pulmonary disease, and paraplegia was applied bilateral supraclavicular, infraclavicular, and axillary blocks at low dose under US guidance.

\section{Case Report}

As a result of an electric shock and fall from height, a 36-year-old male patient in poor general condition, with a $3^{\text {rd }}-4^{\text {th }}$ degree electric burn that had entered the right hand and exited from the left hand, widespread edema in both upper extremities, hemopneumothorax in the left lung, and hemorrhagic effusion in bilateral pleural areas, was admitted to the anesthesia intensive care unit (ICU) for advanced tests and treatment. As no blood flow was observed in the right and left side radial and ulnar arteries on venous Doppler US, anticoagulant treatment of enoxaparin sodium and pentoxifylline was started. Elevation and heat were applied to both upper extremities. In the intervening period, as peripheral circulation did not improve and there were increased swelling and cyanosis, an initial diagnosis of compartment syndrome was considered, and embolectomy and fasciotomy operations were performed under general anesthesia. On the $4^{\text {th }}$ day after ICU admittance, the patient developed pneumonia with deterioration in respiratory and circulatory parameters, so was intubated and attached to a ventilator. On the $12^{\text {th }}$ day, extubation was applied and following 13 days of follow-up in room air, the general condition of the patient improved, so on the $25^{\text {th }}$ day, he was transferred to the burns unit. An operation was planned

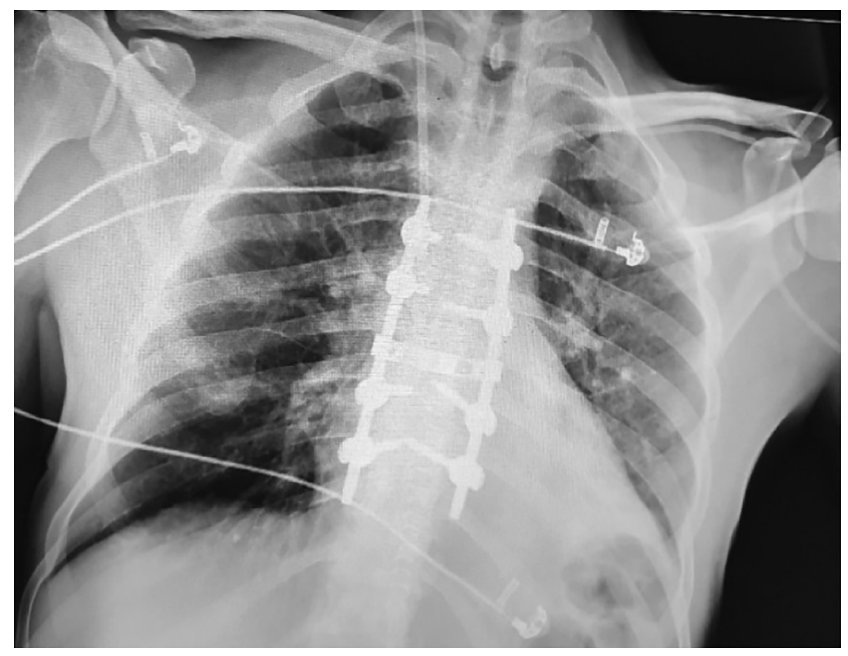

Figure 1. Posterior-anterior chest X-ray of our patient with bilateral pneumonia.

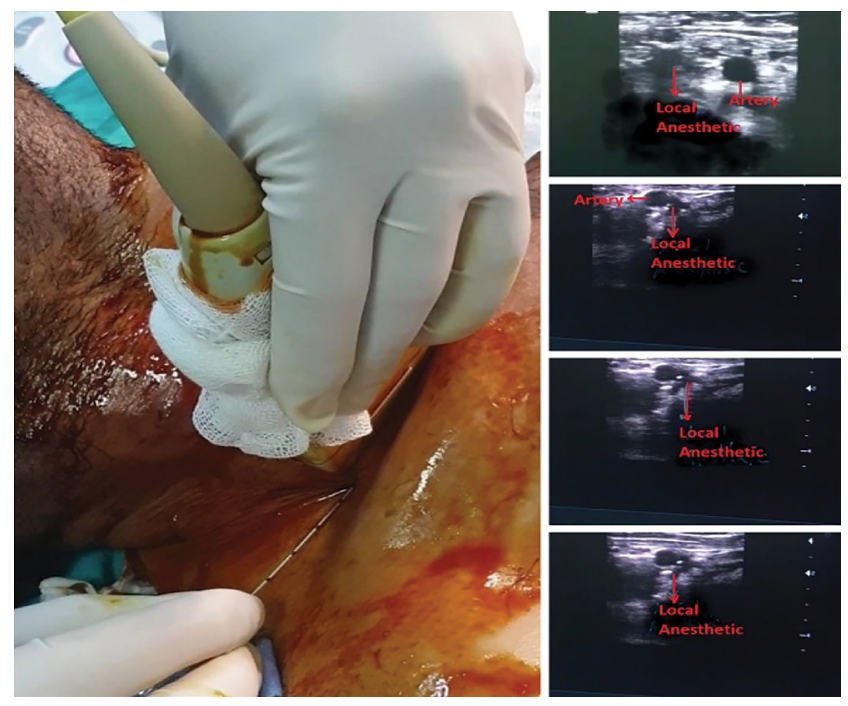

Figure 2. Supraclavicular block application with ultrasonography.

in the burns unit to perform wound debridement to apply vacuum-assisted closure (VAC). In the physical examination for pre-operative evaluation of the patient, infiltrations were determined in both lungs, rales in the lower zones on auscultation, coarsening of the respiratory sounds, and widespread tracheal secretions were observed. Therefore, the patient was evaluated as high risk for general anesthesia (Fig. 1). Repeated regional anesthesia was planned for the patient, and to avoid local anesthesia toxicity, it was decided to apply bilateral supraclavicular block under US guidance. Enlightened consent was obtained from the patient and his relatives. On admittance to the operating theater, the patient was evaluated and measurements were recorded as $110 / 70 \mathrm{mmHg}$ with the arterial blood pressure, pulse was $70 \mathrm{bpm}$, and saturation was $88 \%$ in the toe without oxygen. 

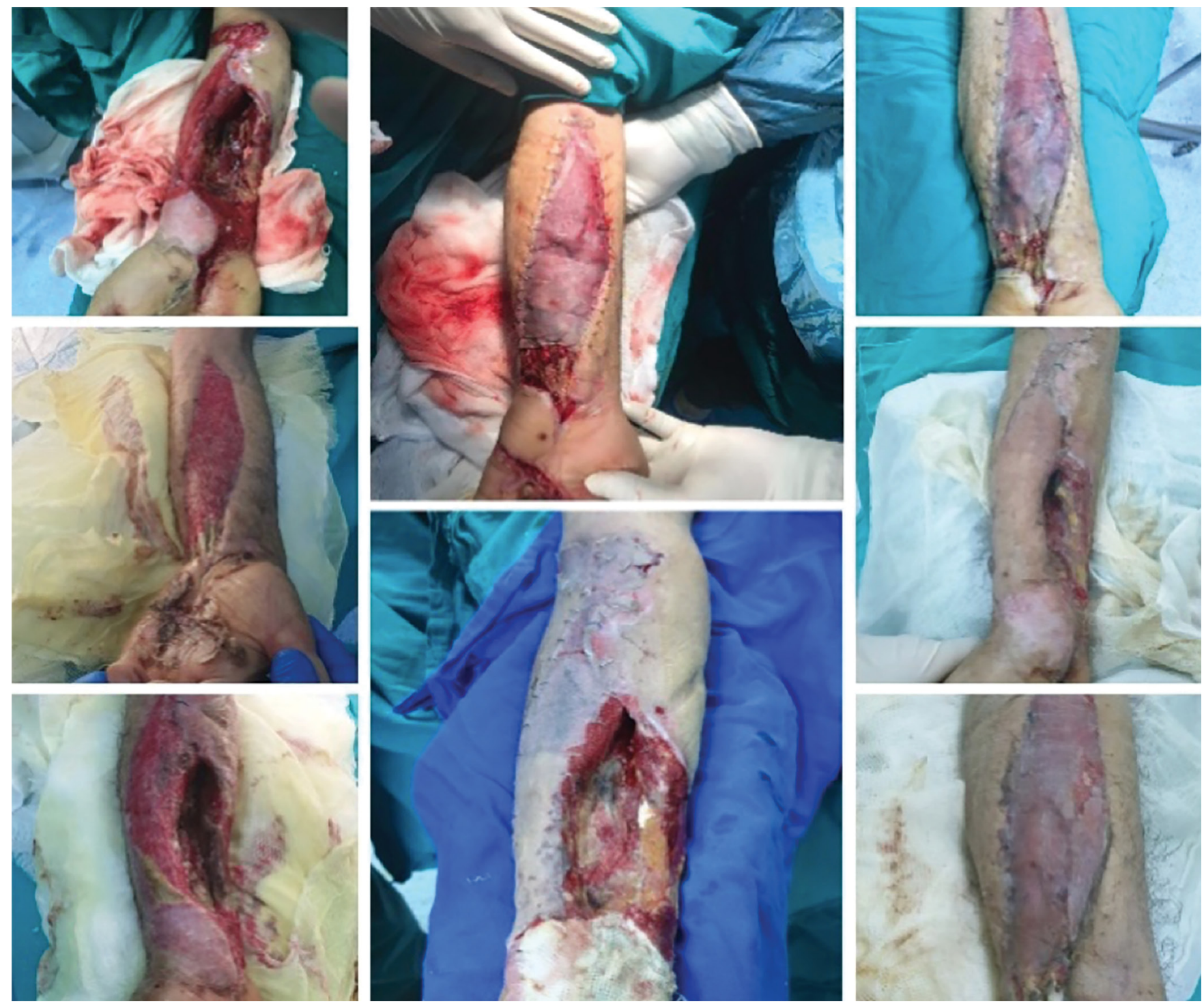

Figure 3. Burns on the upper extremity and deeply injured $3^{\text {rd }}-4^{\text {th }}$ degree.

Oxygen was administered at $2 \mathrm{~L} / \mathrm{min}$ through a nasal cannula. Midazolam $2 \mathrm{mg}$ was administered intravenously. Sterile draping was applied, then first, the cords of the brachial plexus around the supraclavicular artery were visualized with US from the right side. Using a $50 \mathrm{~mm}$ block needle, a total $15 \mathrm{~mL}$ local anesthetic of a previously prepared mixture of $5 \%$ bupivacaine $(10 \mathrm{~mL}=50 \mathrm{mg})$ and $2 \%$ lidocaine $(5 \mathrm{~mL}=100$ $\mathrm{mg}$ ) was injected with intermittent aspiration at the 6,9 , and 12 o'clock positions of the supraclavicular artery. The same procedure was then applied to the left side of the patient (Fig. 2). Following debridement of the areas with tissue loss on the right and left arms, forearms, and hands, these areas were covered with dermis equivalent. Debridement was applied to other areas that had developed granulation tissue and these were covered with thin skin grafts taken from the thigh region without any require- ment for additional anesthesia as the patient was paraplegic. VAC was applied to the areas with grafting on the right side upper extremity (Fig. 3, 4). The operation was completed without any problems in approximately $2 \mathrm{~h}$. No complications were observed in the post-operative follow-up period and there was no requirement for analgesia in this period.

After 5 days, the patient was evaluated for a further operation for wound site debridement, graft care, and VAC application. In the physical examination, rales were still determined in the lower zones of both lungs and on pulmonary imaging, pneumonic infiltrations were seen to be continuing. The patient was considered to be at lower risk and under US guidance, bilateral infraclavicular blocks were applied with a total $15 \mathrm{~m}$ low dose from a mixture of $5 \%$ bupivacaine $(10 \mathrm{~mL}=50 \mathrm{mg})$ and $2 \%$ lidocaine (5 

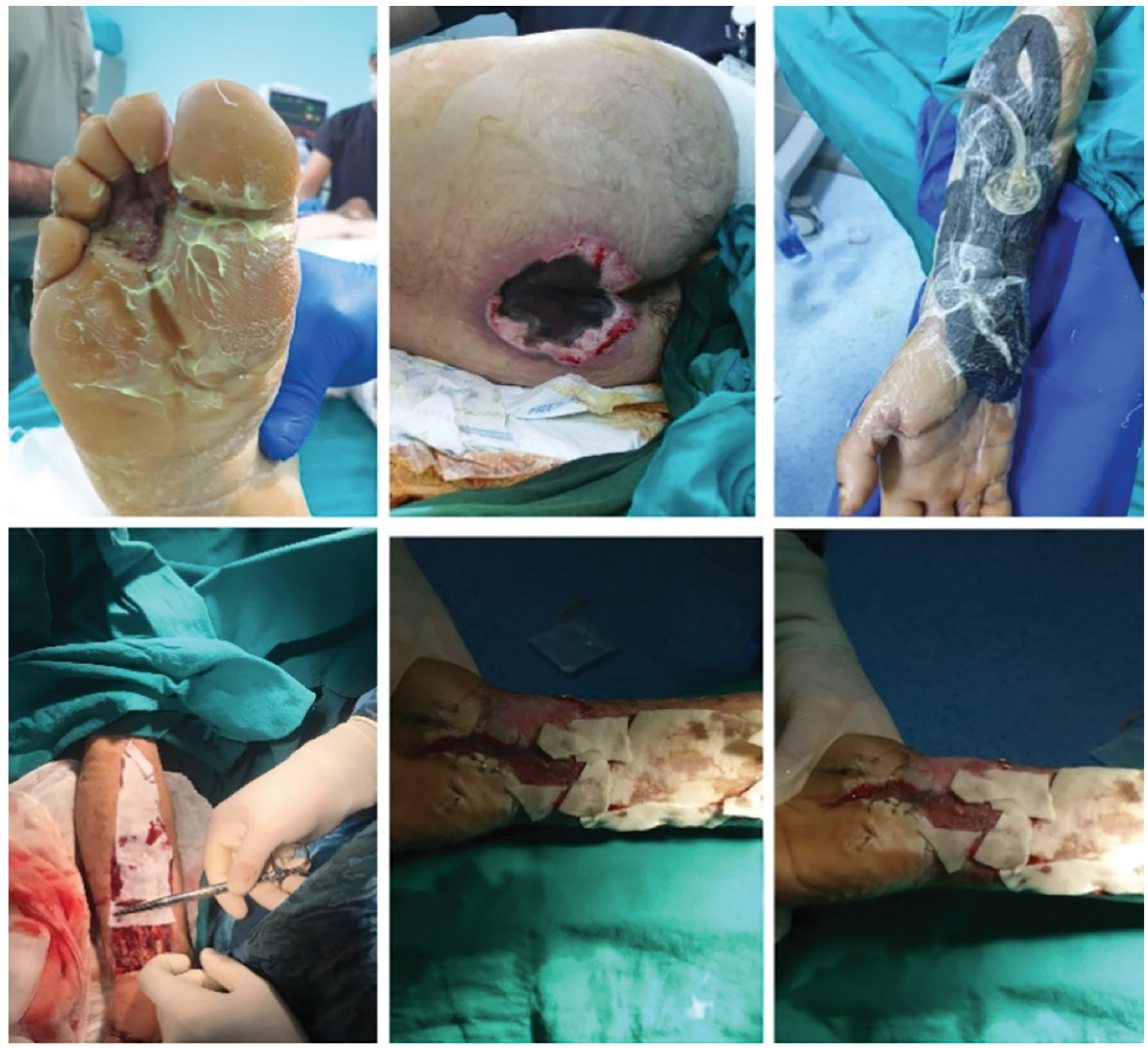

Figure 4. Burns on the upper extremities of the patient in the other extremities for $3^{\text {rd- }-} 4^{\text {th }}$ degree.

$\mathrm{mL}=100 \mathrm{mg}$ ) (Fig. 5). The operation was completed without any problems and no complications were observed in the post-operative follow-up period. One week later, an operation was planned for the same reasons and a reduction in the tracheal secretions of the patient was observed.

However, as the patient had complaints of a cough from time to time, and on the posterior anterior pulmonary radiograph, there was an expansion in the tracheal branches and scattered pneumonia sequelae, low-dose bilateral axillary blocks were applied under US guidance, because of previous concerns. First, $5 \mathrm{ml}$ local anesthetic (5\% bupivacaine and 2\% lidocaine) was administered around the musculocu- taneous nerve. Then, $10 \mathrm{ml}$ local anesthetic (5\% bupivacaine and $2 \%$ lidocaine) was administered with intermittent aspiration to the median, ulnar, and radial nerves around the axillary artery (Fig. 6). No complications were observed in the post-operative follow-up period. In subsequent days, the general condition of the patient and the pulmonary infections improved, so for further debridements and inspection of the grafts, sedoanalgesia and general anesthesia with laryngeal mask were preferred.

\section{Discussion}

The case here presented is of a burns trauma patient at high risk in respect of general anesthesia who was applied repeated peripheral blocks using low-dose 


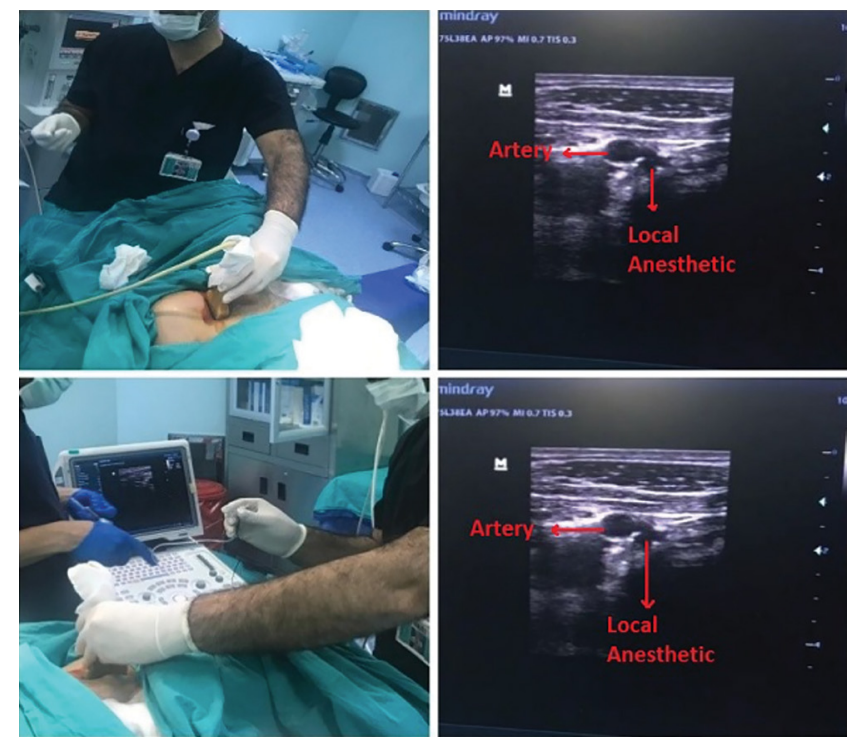

Figure 5. Ultrasonography guided infraclavicular block application.

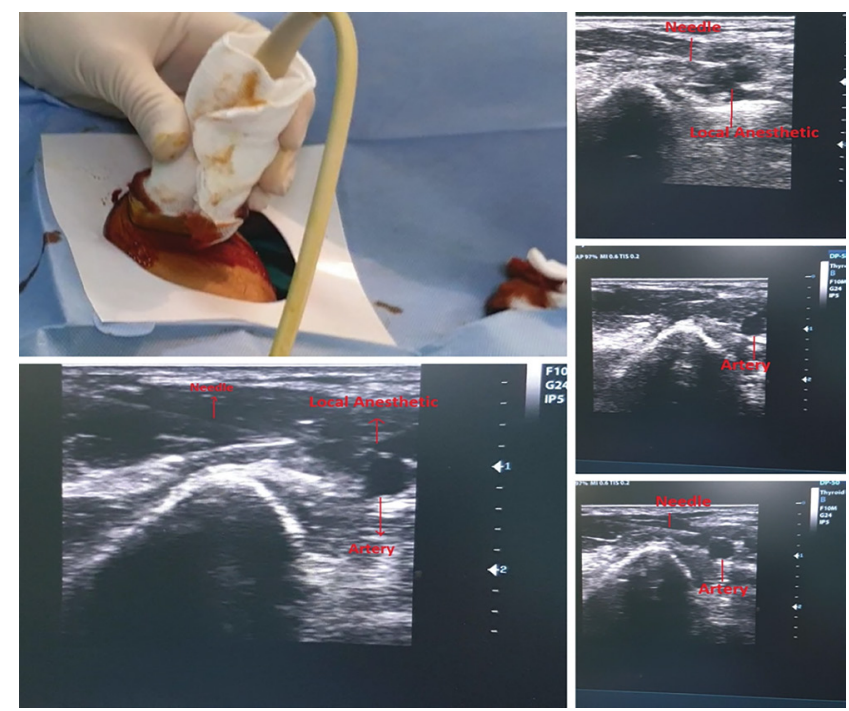

Figure 6. Ultrasonography guided axillary block application.

local anesthetic under US guidance. The applications are here discussed in the light of the relevant literature. The approach to multiple upper extremity surgery applied to patients at high risk for general anesthesia has shown a need for bilateral upper extremity blocks with an increasing need to avoid potential complications. In particular, organ and tissue losses associated with multiple extremity burns formed after burn trauma, and tissue infections require multiple surgical procedures. When these patients are admitted for surgery, anesthetists can experience difficulties at several stages.

Brachial plexus blockage can be applied by interscalene, supraclavicular, infraclavicular, and axillary routes. Although unilateral brachial plexus block is widely applied, bilateral applications of blocks are uncommon and have usually been reported as case reports or small series. ${ }^{[3,5,6]}$ Although bilateral brachial plexus blockage is not greatly preferred by anesthetists because it is time consuming, requires an additional invasive procedure, and has a risk of local anesthesia toxicity, phrenic nerve blockage, and pneumothorax, there are some conditions where it may be preferred. ${ }^{[7]}$ However, with developments in US technology and improved imaging quality, the use is becoming more widespread because of advantages such as the ability to provide limited anesthesia at a low dose and reduced risk of vascular and pleural puncture. In a study by Sandhu et al., ${ }^{[6]}$ it was shown that close to $100 \%$ success could be achieved with local anesthesia applied around the spinal cord using US only.

Brachial plexus block with a supraclavicular approach is characterized by rapid anesthesia onset and a high success rate. As the plexus is nearer the surface in the supraclavicular region, it can be easily visualized. Application of the block is easier and quicker due to the compact structure of the brachial plexus trunk. A standard supraclavicular block requires 30-40 ml local anesthesia, but Soares et al. ${ }^{[8]}$ reported that with appropriate needle position under US guidance, a successful block could be applied with $<20 \mathrm{ml} \mathrm{local}$ anesthetic. Franco et al. ${ }^{[5]}$ reported the application of supraclavicular block to one side and axillary block to the other side with the aid of a nerve stimulator and the operation was completed without any complications. In a case reported by Maurer et al., ${ }^{[3]}$ safe surgical anesthesia was provided by interscalene block on one side and supraclavicular block on the other with $350 \mathrm{mg}$ ropivacaine. In the current patient, bilateral supraclavicular block was applied for the first operation. This block method was used to administer $15 \mathrm{ml}$ local anesthetic bilaterally under US guidance for this patient, as it has a high success rate, rapid anesthesia onset, allows a lower dose of local anesthetic to be administered, and we have more experience of this block.

There is a high risk of the development of pneumothorax in bilateral infraclavicular plexus blocks. Less often, phrenic nerve blockage and systemic local anesthesia toxicity may develop. In a study by Rodriguez ${ }^{[0]}$ investigating the effect on respiratory 
functions of high-volume local anesthetic, $40 \mathrm{ml}$ $1.5 \%$ mepivacaine was administered to 20 patients as a unilateral infraclavicular block and no negative effects on respiratory functions were determined. When the blind technique is used, high-volume local anesthetic injection is applied to obtain an effective block. However, US guidance has made it possible to obtain an effective blockage with a reduced volume of local anesthetic.

Since our patient was at high risk for respiratory tract infection and required repeated surgery and not to apply repeated local anesthesia volume to the same nerve cords of the same plexus, we performed a low dose ( $15 \mathrm{~mL}$ local anesthesia) for each limb with USguided infraclavicular block for the second surgical procedure. The patient did not develop any complications. Apart from the possibility of hematoma and intraneural injection formed by injuries to the general, vascular and nerve structures in the arm and hand region, the approach to the plexus brachialis from the axillary region, which is preferred in arm and hand surgeries, is a safe peripheral block method compared to other brachial plexus blocks in respect of complications such as pneumothorax. Neurological findings are seen in $0.2-19 \%$ of patients applied with single-dose axillary block. ${ }^{[10]}$ With similar concerns arising in the current patient, axillary block was applied twice at the low dose of $15 \mathrm{ml}$ local anesthetic to each side, on observation of healing in the burn injuries below the forearm toward the wrist, and because it is a block causing fewer complications.

\section{Conclusion}

For bilateral upper extremity surgery in high-risk patients with respiratory problems who require repeat- ed operations, low-dose multiple bilateral upper extremity blocks under US guidance are an effective method and safer in respect of preventing complications compared to general anesthesia.

\section{Conflict-of-interest issues regarding the authorship or article: None declared.}

Peer-rewiew: Externally peer-reviewed.

\section{References}

1. Valentin N, Lomholt B, Jensen JS, Hejgaard N, Kreiner S. Spinal or general anaesthesia for surgery of the fractured hip? Br J Anaesth 1986;58(3):284-91. [CrossRef]

2. Brown DL. Brachial plexus anesthesia: An analysis of options.Yale J Biol Med 1993;66(5):415-31.

3. Maurer K, Ekatodramis G, Rentsch K, Borgeat A. Interscalene and infraclavicular block for bilateral distal radius fracture. Anesth Analg. 2002;94(2):450-2. [CrossRef]

4. Marhofer $P$, Greher M, Kapral S. Ultrasound guidance in regional anaesthesia. Br J Anaesth 2005;94(1):7-17. [CrossRef]

5. Franco CD, Salahuddin Z, Rafizad A. Bilateral brachial plexus block. Anesth Analg 2004;98(2):518-20. [CrossRef]

6. Sandhu NS, Maharlouei B, Patel B, Erkulwater E, Medabalmi P. Simultaneous bilateral infraclavicular brachial plexus blocks with low-dose lidocaine using ultrasound guidance. Anesthesiology 2006;104(1):199-201. [CrossRef]

7. Holborow J, Hocking G. Regional anaesthesia for bilateral upper limb surgery: A review of challenges and solutions. Anaesth İntensive Care 2010;38(2):250-8. [CrossRef]

8. Soares L, Brull R, Lai J, Chan V. Eight ball, corner pocket: The optimal needle position for ultrasound-guided supraclavicular block. Reg Anesth Pain Med 2007;32(1):94-5. [CrossRef]

9. Rodriguez J, Bárcena M, Rodríguez V, Aneiros F, Alvarez J. Infraclavicular brachial plexus block effects on respiratory function and extent of the block. Reg Anesth Pain Med 1998;23(6):564-8. [CrossRef]

10. Bergman BD, Hebl JB, Kent J, Horlocker TT. Neurologic complications of 405 consecutive continuous axillary catheters. Anesth Analg 2003;96(1):247-52. [CrossRef] 